\title{
Choosing the Path of Austerity: \\ How Parties and Policy Coalitions influence Welfare State Retrenchment in Periods of Fiscal Consolidation
}

\author{
Klaus Armingeon \\ Kai Guthmann \\ David Weisstanner \\ University of Bern \\ October 2015
}

\begin{abstract}
:
What are the conditions under which some austerity programs rely on substantial cuts to social spending? More specifically, do the partisan complexion and the type of government condition the extent to which austerity policies imply welfare state retrenchment? We demonstrate that large budget consolidations tend to be associated with welfare state retrenchment. Our findings support a partisan and a politico-institutionalist argument: (i) in periods of fiscal consolidation, welfare state retrenchment tends to be more pronounced under left-wing governments. (ii) Since welfare state retrenchment is electorally and politically risky, it also tends to be more pronounced when pursued by a broad pro-reform coalition government. Therefore, we show that during budget consolidations implemented by left-wing broad coalition governments, welfare state retrenchment is greatest. Using long-run multipliers from autoregressive distribute lag models on 17 OECD countries during the 19822009 period, we find substantial support for our expectations.
\end{abstract}




\section{Introduction}

Since the 1980s, austerity has been the dominant topic in the debate on fiscal policies in democratic OECD-nations. Austerity policies are aimed at fiscal consolidation either by cutting public expenditure or raising taxes. Usually both elements are implemented simultaneously with an emphasis on spending cuts that target several policy fields. Yet given its sheer size in public budgets, the welfare state can hardly be spared. What are the conditions under which some austerity programs rely on substantial cuts to social spending?

We combine two main arguments. First, left parties are viewed as trustworthy advocates of the welfare state that would not slash it for narrow ideological reasons, but instead, choose to remodel it in order to keep it sustainable in the long run (see e.g. Ross, 2000). As a result, left-wing governments may be best able to reduce social spending in periods of fiscal consolidation.

The second argument concerns the type of government and the requirement of stable majorities necessary for big reforms, as well as the accompanying electoral risks (Pierson, 1994). The larger a pro-reform coalition, the more likely will adjustment burdens be balanced across electoral groups, and the less likely will a strong parliamentary or extra-parliamentary opposition be present and able to exploit the electoral vulnerability of the governing parties implementing a consolidation. The resulting reform package is therefore more time-consistent and unlikely to be repealed after the next election. This applies to surplus coalitions, but also to minority governments that have to build large policy-field specific parliamentary majorities (Lijphart, 2012: 79-93).

Given these two arguments, we expect the strongest reductions in social spending during fiscal consolidation to be implemented under broad coalition governments with a substantial participation of left-wing parties.

Our hypothesis is in contrast to extant and most recent research. Both Jensen and 
Mortensen (2014) and Hübscher (2015) show that right parties slash the welfare state mostall other things being equal. According to these authors the logic of political competition between left and right produces generally the same substantive outcomes before and during austerity. We challenge this standard argument by using a new data set on austerity, which is hardly analysed in social sciences research (with the exception of Hübscher (2015) and Hübscher and Sattler (2014)), and by estimating a more appropriate model: an autoregressive distributed lag (ADL) general dynamic model without the invalid restrictive specifications often found in standard time series cross-sectional analyses (De Boef \& Keele, 2008).

Even more importantly, we build on established findings of the literature on consensus democracies (Lijphart, 2012: 79-93), on most recent insights about the reform capacity of large coalitions (Alexiadou, 2013) and about the preconditions for policy reform that produce stable and sustainable outcomes in the interest of the common good (Jacobs, 2011). Our article adds to existing evidence that large coalitions are better able to enact policy change than single party governments.

We compile a dataset to compare the experiences with austerity policies in 17 OECD countries during the 1982 to 2009 period. Below, we develop our theoretical argument on the conditions under which partisanship and policy coalitions influence fiscal adjustment programs on social spending. Next, we discuss the operationalization of our core variables, in particular the major independent variable of fiscal adjustment, which is taken from an actionbased dataset of fiscal consolidations by Devries et al. (2011). We then discuss our research design and the statistical technique; finally, we present our empirical findings.

\section{The argument}

In the summer of 1982, the socialist French President Francois Mitterrand learned the hard way, that under severe constraints of liberalized markets for goods and capital, traditional 
Keynesian policies were no longer viable. Reluctantly, the French government implemented austerity policies (Hall, 1986, Chapter 8), marking the beginning of the 'permanent austerity' period in the mature democracies of the Western world (Pierson, 2001). 'Permanent austerity' means that austerity is the dominant topic in the discourse of governing parties. Despite that basic conviction that public deficits must be reduced, public households may still expand due, for example, to demographic or economic reasons such as during the first years of the 'Great Recession', that started in 2008 (Armingeon, 2012; Cameron, 2012). By 2010, full-blown austerity measures were not only back on governments' agendas (except in Japan, Denmark, Norway, and Sweden), but they had returned with a force not witnessed in earlier decades.

It is against this background that we study the impact of austerity policies on the welfare state. Austerity may come in many different forms. Some governments try to consolidate public finances with higher taxes, others focus on cuts in spending, and, probably most frequently, governments opt for a mixture of spending cuts and tax increases (see Von Hagen and Strauch (2001), Tavares (2004), and Mulas-Granados (2006) for economic literature on the composition of fiscal adjustments that partly also finds partisan effects). Spending cuts can be directed towards many policy fields, ranging from reducing subsidies in agriculture, education and military departments, to the overall costs of public administration. One of the most important candidates for cuts, however, is the welfare state. In 2009, public outlays accounted for $49 \%$ of GDP on average in the 23 mature OECD democracies, and about half of these (25\% of GDP) were devoted to the welfare state (calculated from Armingeon et al. (2014)). Therefore, any austerity program is likely to include at least some cuts in welfare state spending.

But which political parties will design a program of fiscal consolidation that most likely focuses on welfare state retrenchment? In a functionalist perspective (see for example Wilensky, 1975) we would expect no correlation at all. The partisan makeup of the 
government may not matter if the pressure exerted by international markets or supranational organizations, such as the EU or the IMF commands austerity, because welfare state cutbacks would then be depicted as natural components in the consolidation of strained fiscal resources. Yet, this argument is blind against the options and electoral calculus of political parties.

A basic argument of the power-resources and partisan theory of welfare state development (see Esping-Andersen, 1990; Hibbs, 1977; Hicks \& Swank, 1992; Korpi, 1983; Korpi \& Palme, 2003; Schmidt, 2010) states that left parties (and with some qualifications Christian democratic parties) are the strongest supporters of the welfare state-well aligned with the interest of their voters (historically from the lower strata of society) in a redistributive safety net. From this perspective, left parties should be most reluctant to pursue austerity policies that imply welfare retrenchment. Liberal and conservative parties, in contrast, have tended to oppose the development and expansion of the welfare state from its emergence, and may, therefore, be more inclined to use the opportunity to decrease social spending. In their analyses of austerity policies, Hübscher (2015) and Jensen and Mortensen (2014) recently provided empirical support for this hypothesis.

These traditional partisan effects may well have dwindled in the era of globalization and austerity (see e.g. Huber \& Stephens, 2001). In fact, the direction of partisan influence could have gone into reverse, now being driven by the logic of welfare state retrenchment, which is very different to the logic of welfare state growth. During its expansion, the welfare state has built its own battalions. Largely irrespective of their ideological orientations, the overwhelming majority of citizens support the welfare state to which they have contributed in the past and from which they expect returns in the future. In consequence, the politics of welfare retrenchment is the politics of blame avoidance (Pierson, 1994). For a number of reasons left parties may be particularly well suited to retrench the welfare state. For example, a left-wing government does not tend to provoke suspicions that it slashes the welfare state on 
narrow ideological grounds, but can build on its reputation as a defender of the welfare state even as it implements cutbacks. This is the so-called 'Nixon goes to China'-effect (see GreenPedersen (2002), Kitschelt (2001). Indeed the politics of the 'new' welfare state may be substantially different from the welfare state's four decades after WWII (Bonoli \& Natali, 2013). Therefore we expect that in times of fiscal consolidation, left-wing governments are more likely to pursue rigorous cuts to welfare state spending than their right-wing counterparts. ${ }^{1}$

Our second argument concerns the type of government. Which one will be best prepared to engage in welfare state retrenchment? Theories of veto players give a clear answer: The odds should be best for centralized one-party governments that are supported by a majority of seats in parliament (see for example Tsebelis, 2002). They do not have to make compromises with coalition partners watering down the austerity plans. They have the necessary majority to pursue a consistent and encompassing policy package. In addition, they can design policies in such a way that the clientele of the opposition mainly bears the costs of the policy. The odds should be second best for minimal winning governments, which include only as many parties as necessary for a parliamentary majority. The odds should be worst for minority governments, which need to build ad hoc coalitions for policies, as well as for oversized coalition governments. Both of these latter forms of government will have to make concessions to other parties, and will have a hard time designing policies that externalize costs to the remaining actors - since most of them are formally (oversized coalition) or informally (minority government) integrated into the government.

What seems to be weakness at first sight, however, could turn out to be strength. In his analyses of consensus democracies, Arend Lijphart demonstrates that these types of

\footnotetext{
${ }^{1}$ Häusermann et al. (2013) nuanced this argument by pointing at the context of electoral institutions, the type of voter-party linkage and general electoral change. However, as a base line, left parties at least did promote the Western welfare state, and we have little reason to assume that they changed as much as to become fierce critics of their own historical project.
} 
democracies, which typically feature oversized coalitions or minority governments, achieve rather favourable and sustainable policy outcomes in processes of negotiation and compromise (Lijphart, 2008, 2012). Majoritarian democracies, in contrast, which typically feature one-party governments or minimal winning coalitions, are prone to 'zick-zack-policies' dictated by electoral cycles and short-term achievements, which tend to be undone by incoming new administrations. If a government intends to govern for the long-term (Jacobs, 2011), however, it makes sense to include all the relevant actors in a reform coalition, to build a consensus and generate trust that costs are shared equally by all actors, and to beware of aggressive cost-externalization. This makes it feasible to invest in the long-term, making compromises and sacrifices in order to facilitate a sound fiscal position and a sustainable welfare state in the future, and to steer clear of short-sighted populist initiatives for immediate but short-lived political gain (see also the argument about cooperative veto-points by Birchfeld \& Crepaz, 1998; Crepaz, 1996; Crepaz, 1998). A major advantage of this approach is the reduction of the electoral costs of austerity and social security cutbacks. By definition, only few actors are excluded from a broad coalition. In consequence, there are only few actors available outside the coalition, which could organize a powerful opposition to, and launch a potent electoral campaign against the government implementing unpopular reforms and cutbacks. Alexiadou (2013) provides strong empirical evidence for such counter-intuitive effects of broad coalitions. Bonoli (2000) finds similar results for pension reforms.

Our central argument about the type of government should not be confused with the argument of blame avoidance by obfuscation. Jensen and Mortensen (2014) show that welfare state retrenchment is facilitated by a large number of veto points (institutional fragmentation), since under these conditions blame attribution is difficult. While these authors explicitly exclude the type of government, we consider it to be a major explanatory variable for retrenchment. In other words, we emphasize a causal chain that works through the rational 
strategy of political actors to minimize opposition by inclusion, and the mutual and balanced compensation of electoral constituencies. Jensen and Mortensen (2014), in contrast, point to the logic of blame avoidance by obfuscation, which constitutes a second causal chain that may certainly also be at work.

Our arguments about the impact of the partisan complexion and the type of government on welfare state retrenchment in times of austerity can be condensed into the following hypothesis:

Fiscal consolidation programs implemented by left-wing broad coalition governments are associated with relatively large reductions in public social expenditures.

All other things equal, both the presence of a left-wing government or that of a broad governing coalition should by itself tend to foster welfare state retrenchment in periods of fiscal consolidation. We therefore expect the strongest reduction in public social spending to occur if both conditions are met simultaneously. Alternatively, fiscal adjustments implemented by non-left narrow coalition governments should be least likely to lead to a substantial trimming of the social safety net.

Moreover, at the beginning of this section we have emphasized the substantial relative weight of welfare-related items in public budgets. As a result of this weight, the degree of welfare state retrenchment should be associated with the size of a fiscal consolidation package. While a relatively minor adjustment may be realized without touching social security, any big program can hardly shun social policies. By implication, relatively large austerity programs in particular should be associated with decreasing public social expenditures. In addition to that, also the magnitude of both our partisan and our government type effect may be affected by the size of an austerity program: they are likely to be more pronounced when a fiscal consolidation is particularly large. In addition to our major hypothesis, we will therefore 
examine the implicit assumption that both (a) the main effect of a consolidation on the welfare state, and (b) the conditional impact of parties and the type of government on this relationship, are more pronounced in the context of relatively large austerity programs.

\section{Data and Operationalization}

The focus of this paper is on the degree to which fiscal consolidation implies welfare state retrenchment. In other words, is the welfare state - conditioned by the partisan complexion and/or the type of government — at the core of policies intended to reduce budget deficits and debts?

Against this background, it becomes apparent why we conceptualize welfare state retrenchment exclusively in quantitative budgetary terms. We treat the welfare state simply as one of the most important spending categories of government budgets-and for its redistributive function the size of this category tends to be strongly associated with income inequality. The welfare state's more qualitative features, such as its institutional structure, its program coverage, or generosity, are not at the core of this paper. Therefore, we do not analyse the extent to which fiscal adjustments imply a rebalancing of the welfare state, such as, for instance, a stronger emphasis on family or active labour market policies at the expense of pension or health policies.

Our dependent variable is operationalized as the annual change (first differences ${ }^{2}$ ) in total public social expenditures as a percentage of GDP, as provided by the OECD. ${ }^{3}$ The use of change rates (as opposed to levels) is, from a theoretical point of view, implied by our

\footnotetext{
${ }^{2}$ Operationalizing the change rate as percentage changes does not alter our substantive results.

${ }^{3}$ To measure social expenditure as a share of GDP is conceptually superior over measuring it as a share of total public spending. Imagine a country implementing a uniform $10 \%$ cut to all spending categories (that is, both welfare- and non-welfare-related budget items are equally hit). The net effect of fiscal adjustment on social expenditure as a percentage of total expenditure would then, misleadingly, be zero. Further research could analyse whether these welfare state effects of fiscal consolidation vary by field of social policy, such as pension policy or unemployment insurances (see Wenzelburger, 2014).
} 
research question: we wish to know what changes during and after fiscal adjustment - the size of the welfare state per se (as measured by levels of public social expenditures) is not of much relevance to us. A methodological justification for this operationalization is provided below. OECD public social expenditure data is available from 1980 onwards. Since we are using first differences and including a lagged dependent variable (LDV) in our statistical models, our observation period begins in 1982 (1991 for Austria).

Our main independent variable is the occurrence of fiscal consolidation, but we also distinguish between different sizes of consolidations. The standard approach in comparative political economy to operationalize fiscal consolidation starts from changes in countries' primary budget balance (Wagschal \& Wenzelburger, 2008b, 2012) or its cyclically adjusted version (CAPB) (Alesina \& Ardagna, 2009). A noticeable improvement in this balance (i.e., a sharp reduction in budget deficits) indicates fiscal adjustment (FA). For example, Alesina and Ardagna (2009, p. 41) code a year as one of FA if the budget balance improves by at least 1.5 percentage points of GDP. More recently, however, the literature on the topic has become sceptical about the validity of this operationalization of FA based on the primary balance or CAPB (IMF, 2010, p. 96; Wenzelburger, 2009).

These indicators measure the outcome of consolidations, instead of looking at consolidation policies - which are at the core of our theoretical interest here, and may or may not have caused measured outcomes. The CAPB is seen as a remedy to capture discretionary policy changes by adjusting primary balances for the effects of the business cycle. The methods to correct for cyclical changes, however, are usually inconsistent across different data sources and suffer from "measurement errors that are likely to be correlated with economic developments" (IMF, 2010, p. 96). And even if an exact cyclical correction were possible, the political motivations behind the resulting figures would still be disregarded. To 
sum up, the overall validity of such outcome-based indicators of fiscal adjustment policies is questionable.

Therefore, a different approach aims at explicitly identifying tax hikes and spending cuts passed by political actors at the general government level. This so-called historical or action-based approach underlies the work by Devries et al. (2011), who collected a dataset of policy measures (i.e., this is no data on budget balances/deficits) motivated explicitly by fiscal consolidation (rather than by restraining aggregate demand during periods of strong growth, for instance) in 17 OECD countries between 1978 and 2009. ${ }^{4}$ With respect to our sample and observation period, the authors identify a total of 159 country-years of FA based on policy documents like central bank reports, budget speeches, OECD, IMF, and EU sources, and provide estimates of the budgetary impact of these measures in percent of the GDP. ${ }^{5}$ Note that these measures were not only planned, but actually taken by governments; only their budgetary impact is based on estimates.

We construct binary variables indicating FA episodes. The continuous variablebased on the size of adjustment in percentage of GDP - is censored in the sense that it does not properly distinguish between 'no-FA-cases' and FA of zero or very small size. Therefore, in order to distinguish between 'no-FA-cases' on the one hand, and those of different sizes on the other, the data enters our statistical analyses in one of two ways: a general FA dummy variable that equals 1 for all 159 FA cases in the sample and 0 otherwise, and a dummy variable to identify large fiscal adjustments. ${ }^{6}$ In line with the most commonly used threshold

\footnotetext{
${ }^{4}$ These countries are Australia, Austria, Belgium, Canada, Denmark, Finland, France, Germany, Ireland, Italy, Japan, the Netherlands, Portugal, Spain, Sweden, United Kingdom, and the United States.

${ }^{5}$ In 19 of these cases, spending cuts were partly offset by tax cuts, or tax increases were partly offset by spending increases. In addition, the expiration of temporary fiscal adjustment measures resulted in negative FA sizes in eight instances (Devries et al. 2011: 6).

${ }^{6}$ The 'negative FA sizes' resulting from the expiration of temporary measures as discussed in the previous footnote are coded as zero FA size (all results are robust, however, if we exclude temporary measures and only include permanent ones). Note that our action-based data only covers fiscal consolidations, not fiscal expansions. Indeed, the overall fiscal stance of the government as measured based on budget balances, and which also underlies the traditional outcome-based approach to operationalizing fiscal consolidations, could be neutral or even expansionary during a consolidation as identified in the action-based approach.
} 
in economic research (see Alesina \& Ardagna, 2009; IMF, 2012, p. 53; Wagschal \& Wenzelburger, 2008a) consolidations exceeding $1.5 \%$ of GDP qualify as 'large'. Using continuous versions of these dummy variables ${ }^{7}$ does not, however, alter our findings. We restrict our analysis to the set of countries and time periods covered by the Devries-data set. Table 1 provides an overview of all fiscal adjustment cases in our sample.

\section{[Table 1 about here]}

The other major independent variables are the partisan complexion of governments and the breadth of the policy coalition. Both are operationalized as binary variables based on data from Armingeon et al. (2014). With respect to government partisanship, we use data for the percentage of cabinet posts occupied by left-wing parties. A dummy variable is coded 1 if left parties held more than $50 \%$ of cabinet posts in a given country-year. While cabinet shares do not always exactly reflect the real distribution of power within governments, our dummy indicating an absolute majority is likely to indicate a government dominated by left ideology. Moreover, around $63 \%$ of all governments in our sample have a left party cabinet share of either $100 \%$ or $0 \%$. Adjusting the dummy variables so that exactly $50 \%$ of cabinet posts also indicate left-wing governments or using the continuous version of the variable, does not alter our findings. ${ }^{8}$

The breadth of the policy coalition is operationalized as a dummy variable based on the type of government. If a government is a surplus coalition in the sense that it has more parties than needed for a parliamentary majority, it is classified as a 'broad' coalition (dummy

\footnotetext{
${ }^{7}$ In its original form, our continuous FA variable varies between -0.75 and 4.74 . Derived from this is the continuous 'large FA' variable, set to zero whenever FA was smaller or equal to $1.5 \%$ of GDP (also see IMF (2012, p. 50 ff.) for this operationalization).

${ }^{8}$ Our overarching empirical strategy builds on comparing different groups of governments, distinguished by their partisan complexion and coalition breath. This is why we prefer to operationalize all our major independent variables of interest as binary variables. Nevertheless, operationalizing the partisan complexion of government as a continuous variable (i.e. the cabinet shares), only strengthens our results.
} 
= 1). Likewise, minority governments usually negotiate policy-specific majorities - they would otherwise not be able to shape the legislative process - and are thus also classified as broad coalitions. Single party or minimal winning coalition governments, in contrast, are classified as 'narrow' coalitions (dummy $=0$ ). Our results are robust to alternative operationalizations based on a certain threshold of parliamentary seat shares as a necessary condition to classify a government as 'broad' coalition. ${ }^{9}$

In order to examine the effects of the partisan complexion and the type of government on the relationship between austerity and social expenditures, we construct interaction terms between each of our two FA variables on the one hand, and the partisanship dummy as well as the coalition breadth dummy on the other. Finally, we construct dummy variables integrating our three major independent variables into four groups against the reference group of "no-FAcases'. These four group-dummy variables indicate FA (or large FA) cases under (1) left-wing broad coalition governments, (2) left-wing narrow coalition/single party governments, (3) non-left broad coalition governments, and (4) non-left narrow coalition/single party governments. Figure 1 shows the descriptive relationship between these four types of government and the average changes in social expenditures. We use the total change of the current and the subsequent years since we are interested in long-run effects (see below). In line with our hypothesis, fiscal adjustments under left-wing broad coalition governments are negatively associated with social expenditure changes.

\section{[Figure 1 about here]}

Our control variables include standard economic factors such as economic growth (data from

\footnotetext{
${ }^{9}$ In this operationalization, 'broad' coalitions are governments that are not single-party majority governments and that simultaneously have a seat share in parliament of at least 60 or $70 \%$. Minority governments also count as 'broad'. Among others, this operationalization ensures that 'grand coalitions' such as the coalition Austria in 2009 are treated as 'broad' as well.
} 
OECD, 2012), annual changes in unemployment rates (OECD, 2010b), and economic openness (Heston et al., 2012). In the short-run, as automatic stabilizers begin to work, poor economic performance leads to higher social expenditures. In the long-run, lower performance is expected to decrease the potential for social spending and can thus be perceived as an indicator for (higher) problem pressure. We control for additional driving forces of social expenditure as identified in the literature (see Kittel \& Obinger, 2003). First, we include the lagged level of social expenditures in order to account for catch-up and ceiling effects. The second is the share of elderly people in the population (data from OECD, 2010b). The third is a measure for the funding structure of the welfare state, constructed as social security contributions divided by total tax revenues (OECD, 2010a). This contrasts tax-based versus insurance-based welfare regimes, where the former is expected to be affected more directly when governments consolidate (see Kittel \& Obinger, 2003, p. 31). Finally, we control for institutional arrangements by including the Rae index of legislative fractionalization of the party system (data from Armingeon et al., 2014).

Details on the operationalization and sources of all variables, as well as summary statistics, are found in the online appendix.

\section{Method}

We compile a time-series cross-sectional (TSCS) dataset comprising of 466 country-year observations between 1982 and 2009. The data is balanced except for the missing data on Austria.

As discussed above, we have theoretical reasons to operationalize our dependent variable as first differences. There is, however, also a purely methodological justification for this approach. First, when specifying the dependent variable in levels, our data suffers from unit heterogeneity — a problem that is commonly solved by adding unit dummies to the model, 
i.e., fixed-effects estimation. Second, the level-version of the dependent variable has a unit root (and therefore is non-stationary), as was indicated by a battery of augmented DickeyFuller tests for panel datasets. A solution that often solves both problems simultaneously is to run the regression using first-differences, a strategy we therefore apply for methodological reasons as well. ${ }^{10}$

Most of our control variables also enter the analysis in first differences. We stick to levels, however, whenever it made sense theoretically and when the level variable turned out to have more explanatory power than the corresponding operationalization in changes.

A common downside of a model specification in first differences is the implicit assumption about the temporal effect of a change in $\mathrm{x}$ on $\mathrm{y}$-i.e., that a change in $\mathrm{x}$ causes a change in y only once (instantaneously or with a constant lag) and then fades immediately. This usually prevents the researcher to draw inferences about the long-term consequences of policy changes that are central to much of the research in comparative political economy.

We mitigate this problem by estimating a distributed lag model where we include our FA variables not only at $\mathrm{t}$, but also with a one-year as well as a two-year lag ( $\mathrm{t}-1$ and $\mathrm{t}-2)$. With respect to the lag structure of the control variables, we follow the recommendation by De Boef and Keele (2008) and start with a general model (i.e., include contemporaneous variables as well as their lags) and impose restrictions only when empirically justified-i.e., when the respective variable did not have any substantial explanatory power. ${ }^{11}$

We include a lagged dependent variable (LDV) to address serial correlation. As there still is autocorrelation and panel heteroskedasticity, as well as cross-sectional dependence,

\footnotetext{
${ }^{10}$ An alternative specification commonly used in the context of non-stationary data in time-series- and TSCSanalysis - estimation based on an error correction model (ECM) - is not possible with our data since the crucial assumptions behind this method do not hold: neither are the time-series in question both stationary, nor are they co-integrated (and thus both have unit roots) (De Boef \& Keele, 2008). Rather, our dependent variable (in levels) has a unit-root, while our main independent variables of interest are stationary.

${ }^{11}$ We settled on a maximum lag length of two years for all explanatory variables, partly because we did not find any significant effect afterwards (for the FA variables), partly to keep the model as parsimonious as possible (for the controls).
} 
present in our data, we include country and year fixed effects and apply OLS estimators with panel-corrected standard errors. ${ }^{12}$ In a first step, we thus estimate autoregressive distributed lag (ADL) models, formally specified as

$$
\begin{aligned}
\Delta y_{i t} & =\alpha_{0}+\alpha_{1} \Delta y_{i t-1}+\sum_{k=0}^{2} \beta_{k} F A_{i t-k}+\sum_{k=0}^{2} \gamma_{k} Z_{i t-k} \\
& +\sum_{k=0}^{2} \delta_{k}(F A * Z)_{i t-k}+\sum_{j=1}^{6} \sum_{k=0}^{2} \zeta_{j k} \text { control }_{j i t-k}+e_{i t}
\end{aligned}
$$

where $\Delta y_{i t}$ represents the change in total public social expenditures in country $\mathrm{i}$ from time $\mathrm{t}-1$ to $\mathrm{t}, \alpha_{0}$ is the constant, and $\alpha_{1}$ is the coefficient of the LDV. $Z$ stands for the dummy indicating the partisan composition of government, or the breadth of the policy coalition, respectively - that is, in a first step, we estimate partisan and coalition effects separately in two series of models. $\beta_{k}, \gamma_{k}$, and $\delta_{k}$ are three coefficients each (i.e. at t, t-1, and t-2) for the relevant FA dummy (FA or FA large), the partisan/coalition dummy, respectively, and the FA*partisan/coalition interaction term. Moreover, $\zeta_{j k}$ are coefficients for our seven control variables at a maximum of three time points each. Finally, $e_{i t}$ is an idiosyncratic error term. In a second step, equation (1) is slightly altered as we include four indirect interaction terms comprising the dummy variables for the four sub-groups of FA cases by partisan complexion (left and non-left) and coalition type of governments (broad and narrow) as the main parameter terms.

Our theoretical interest clearly is in the more long-run aggregate impact of fiscal adjustment on change rates in social expenditures. In the empirical analysis, we therefore proceed by calculating this long-run effect (known as the long-run multiplier (LRM) in the

\footnotetext{
${ }^{12}$ Serial correlation was detected with Wooldridge tests for autocorrelation. Hausman tests, joint F-tests and Pesaran tests for cross-sectional dependence indicate significant differences across units (panel effects). Modified Wald tests show the presence of panel heteroskedasticity. All tests are significant at the $99 \%$ level. Finally, we have no indications for severe problems with multicollinearity: the highest average VIF in any of our models is 4.02. All analyses were run in Stata 13.
} 
time-series literature) of fiscal adjustment from the coefficients of our contemporaneous and lagged FA variables as well as from the relevant partisanship or coalition interaction terms.

Substantively, the resulting battery of LRMs (for both of our FA variables under different government ideology or coalition breadth) gives the total effect of fiscal adjustment on change rates in social expenditures over a period of 3 years-i.e., the immediate effect (impact multiplier) plus the effect that occurs with a one and two year lag.

Slightly adjusted to the context of our analysis, the formula for calculating the LRM of the FA variable in the ADL model of equation (1) is given as $L R M 0=\eta_{0}=\left(\beta_{0}+\beta_{1}+\beta_{2}\right) /$ $\left(1-\alpha_{1}\right)$ when the partisan/coalition dummy equals zero, and as $L R M 1=\eta_{1}=\left(\delta_{1}+\delta_{2}+\right.$ $\left.\delta_{3}\right) /\left(1-\alpha_{1}\right)$ when it equals one (i.e. the LRM of the interaction term) (De Boef \& Keele, 2008). In order to obtain the standard error for these LRMs, we follow the procedure described by Wooldridge (2013, pp. 134-135). ${ }^{13}$ That is, we solve the LRM formulas for $\beta_{0}$ and $\delta_{0}$ to obtain $\beta_{0}=\eta_{0}\left(1-\alpha_{1}\right)-\beta_{1}-\beta_{2}$ and $\delta_{0}=\eta_{1}\left(1-\alpha_{1}\right)-\delta_{1}-\delta_{2}$ and substitute that for $\beta_{0}$ and $\delta_{0}$ in equation (1), which leads to equation (2). Finally, equation (2) is estimated with the estimate for $\alpha_{1}$ being obtained from equation (1) in advance.

$$
\begin{gathered}
\Delta y_{i t}=\alpha_{0}+\alpha_{1} \Delta y_{i t-1}+\eta_{0}\left(1-\alpha_{1}\right) F A_{i t}+\sum_{k=1}^{2} \beta_{k}\left(F A_{i t-k}-F A_{i t}\right) \\
+\sum_{k=0}^{2} \gamma_{k} Z_{i t-k}+\eta_{1}\left(1-\alpha_{1}\right)(F A * Z)_{i t} \\
+\sum_{k=1}^{2} \delta_{k}\left((F A * Z)_{i t-k}-(F A * Z)_{i t}\right)+\sum_{j=1}^{6} \sum_{k=0}^{2} \zeta_{j k} \text { control }_{j i t-k}+e_{i t}
\end{gathered}
$$

\footnotetext{
13 As an alternative method to calculate the standard errors of the LRMs, we employed the Bewley transformation (De Boef \& Keele, 2008, p. 192). This yielded slightly smaller standard errors, but we report only the more conservative estimated in this analysis.
} 


\section{$5 \quad$ Empirical Findings}

Table 2 shows the results of our main regression analyses. ${ }^{14}$ Models 1 through 4 estimate the effects based on all fiscal adjustment (FA) cases on changes in public social spending, while models 5 through 8 estimate those based only on large FA cases (FA size larger than $1.5 \%$ of GDP). For both operationalizations, the first model of each group shows the unconditional effects; the second and third show the interaction effects of FA and government ideology/coalition breadth; and the fourth model estimates the effects of FA under the four categories of governments against the reference group of cases where no FA took place.

\section{[Table 2 about here]}

As indicated by the coefficients for the LRM in models 1 and 5, fiscal consolidation is associated with shrinking public social expenditures over a period of three years at least (i.e., an immediate effect plus effects with a one-year and a two-year lag). Yet, this average effect is only significant for large FA. In total, during the period when a large fiscal consolidation program was enacted, the change rate of public social expenditures is reduced by 0.49 percentage points. The magnitude of this effect is comparable to the immediate positive effect that a 5.7 percentage point increase in the unemployment rate has on social expenditures (likely due to the associated increase in expenditures on unemployment benefits). The general pattern is that the coefficients estimated based on large FA cases (models 5-8) strongly amplify the negative effect on social expenditure changes found when all—both small and large-fiscal adjustments are taken into consideration (models $1-4) .{ }^{15}$

\footnotetext{
${ }^{14}$ We do not discuss the coefficients of the control variables, which confirm our theoretical expectations. For results of robustness tests and concerns with regard to endogeneity see the online appendix.

${ }^{15} \mathrm{We}$ are not formally testing the effect of the size of FA in our models by way of three-way interactions, as these are difficult to implement technically for distributed lag models and drastically reduce the number of cases
} 
These aggregate effects, however, mask some substantial variation in the impact of political factors on the degree of welfare state retrenchment. The significant interaction terms in models 2 and 6 show that in times of austerity, retrenchment is more pronounced under left governments than under non-left ones. Likewise, fiscal consolidations pursued by broad coalition governments tend to place more emphasis on trimming the social safety net than narrow coalitions do, as is indicated by the interaction terms in models 3 and 7. Some uncertainty remains with respect to both of these effects, however, since their statistical significance often turns out to be sensitive to sample modifications. ${ }^{16}$

While we cannot eliminate this uncertainty altogether, we try to mitigate the problem by looking at the two political factors simultaneously in models 4 and 8 . These models disentangle the effects of partisanship (left vs. non-left) and government type (broad vs. narrow) by estimating the effects of all four combinations that can be formed from these two binary factors separately. Here we find a very clear pattern: left-wing broad coalition governments are associated with the strongest reduction in social spending in periods of fiscal consolidation. In contrast, adjustments under non-left narrow coalition governments may even lead to welfare state expansion (although this effect is not significant for large FA). The difference in the effect of fiscal adjustment between these two groups (i.e., difference in their coefficients) is highly significant (t-values in italics). The middle group for the effect of FA is constituted by left narrow coalition governments and non-left broad coalition governments. For the most part, these two middle groups do exhibit some significant welfare state retrenchment following the implementation of their austerity programs. These effects,

for each subgroup. However, the difference in coefficients between models 1-4 and 5-8 allows us to confidently state the reinforcing negative effect of large FA.

${ }^{16}$ The interaction term between FA and broad coalitions (model 3) misses the $90 \%$ significance level when Sweden, Finland, France, Ireland, Portugal, or Spain are excluded. For large FA (model 7), the coalition effect is not significant when Ireland is excluded from the sample. Likewise, the interaction term between large FA and left governments (model 6) is not significant when cabinets with 50\% share of left parties also are operationalized as left governments. The direction of all these insignificant interaction effects remains as theoretically expected. 
however, do not hold up well in all of the robustness tests. Moreover, we do not find consistent indications that the magnitude of these effects is significantly different from those found in the other groups. ${ }^{17}$

Arguably partisan effects could differ by sectors of the welfare state, e.g. labour market policies versus pensions (Jensen \& Mortensen, 2014). It is beyond the scope of this article to fully replicate our analyses on the basis of thoroughly disaggregated social expenditure data. As we show in the online appendix (Table A3), however, our findings are robust if we exclude spending on pensions and/or health care.

We conclude that both the predominance of left parties in government and the presence of broad policy coalitions tend to foster welfare state retrenchment during austerity periods. These effects are mutually reinforcing. Moreover, if the adjustment program is large, this decisively strengthens the negative effect on the welfare state. Therefore, only the combination of all three factors - left-wing government, broad coalition, and large FA—leads to fiscal consolidations being associated with an unequivocal contraction in the trajectory of social expenditure growth, thus lending empirical support for our main hypothesis.

\section{Conclusion}

What are the conditions under which some austerity programs rely on substantial cuts to social spending? More specifically, do the partisan complexion and the type of government condition the extent to which austerity policies imply welfare state retrenchment? We argue that welfare state retrenchment is greatest when implemented by left-wing broad coalition governments, in particular in the context of large fiscal consolidations.

\footnotetext{
${ }^{17}$ The volatility in the coefficient estimations for these two middle groups is demonstrated by the conservative test of excluding whole countries from the sample. For example, the coefficients from model 8 for left narrow governments vary between $-1.81 * * *$ excluding Portugal to -0.68 (n.s.) excluding Belgium. Similarly, for non-left broad governments, the coefficients from model 8 vary between -0.53 (n.s.) excluding Ireland and $-1.00 * *$ excluding Italy.
} 
With regard to data and methods, this paper offers two innovations. First, it starts from policy programs as valid indicators of fiscal consolidation, and not from their outcomes of austerity measures. These outcomes may be confounded by many other variables and can therefore hardly be considered valid indicators of what we want to explain: how austerity programs are implemented and how they influence policy outcomes. Second, by introducing various lags of our main independent variables in an autoregressive distributed lag design, we are able to calculate the long-run impact of fiscal adjustment programs on welfare state retrenchment. Most research relying on analysis of cross sectional time series start with rather restricted models and heroic assumptions about the temporal effects between a change in the independent and the dependent variables. Calculating the long run effects based on distributed lags - as we have done it in this article - may be a useful strategy to solve these problems, which are frequently ignored in standard TSCS analyses of fiscal adjustments and welfare state reform.

In substantive terms, we offer an explanation, which is based on the combination of a partisan and a type of government argument. With regard to the partisan logic, we observe a 'Nixon goes to China' scenario (Kitschelt, 2001). Left-wing governments tend to be significantly better able to target the welfare state than non-left governments are, which we essentially explain with their historical reputation as long-standing welfare state founders and defenders. With regard to the type of government, we find that broad pro-reform coalitions (surplus or minority governments) tend to be most likely to implement consolidations that trim the social safety net. This is due to the lower political and electoral risks, as well as, the higher time-consistency associated with policy-packages that are conceived and supported by broad pro-reform coalitions. 


\section{Tables}

Table 1: Occurrences of Fiscal Adjustment by Government Partisanship and Government Type

\begin{tabular}{|l|rr|rr|}
\hline & \multicolumn{2}{|c|}{ All FA cases } & \multicolumn{2}{c|}{ Large FA only } \\
& \multicolumn{1}{|c|}{ FA } & \multicolumn{1}{c|}{ No FA } & \multicolumn{1}{c|}{ FA } & No FA \\
\hline Total (n=466) & $159(34 \%)$ & $307(66 \%)$ & $37(8 \%)$ & $429(92 \%)$ \\
& $46(35 \%)$ & $87(65 \%)$ & $6(5 \%)$ & $127(95 \%)$ \\
Left Governments (n=133) & $113(34 \%)$ & $220(66 \%)$ & $31(9 \%)$ & $302(91 \%)$ \\
Non-Left Governments (n=333) & & & & \\
& $56(28 \%)$ & $147(72 \%)$ & $18(9 \%)$ & $185(91 \%)$ \\
Broad Coalitions (n=203) & $103(39 \%)$ & $160(61 \%)$ & $19(7 \%)$ & $244(93 \%)$ \\
Narrow Coalitions (n=263) & & & & \\
& $20(29 \%)$ & $48(71 \%)$ & $3(4 \%)$ & $65(96 \%)$ \\
Left \& Broad Gov. (n=68) & $26(40 \%)$ & $39(60 \%)$ & $3(5 \%)$ & $62(95 \%)$ \\
Left \& Narrow Gov. (n=65) & $36(27 \%)$ & $99(73 \%)$ & $15(11 \%)$ & $120(89 \%)$ \\
Non-Left \& Broad Gov. (n=135) & $77(39 \%)$ & $121(61 \%)$ & $16(8 \%)$ & $182(92 \%)$ \\
Non-Left \& Narrow Gov. (n=198) & & &
\end{tabular}

Figure 1: Average long-run changes of social expenditure under FA and large FA
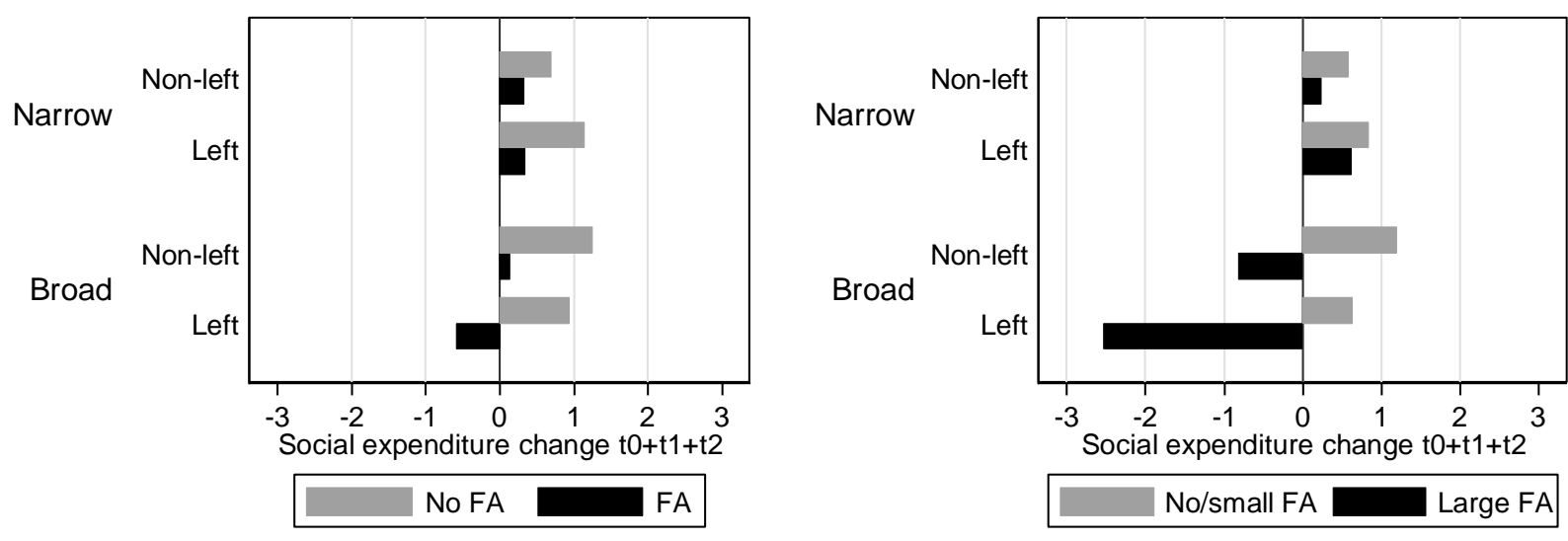
Table 2: Determinants of Changes (first differences) in Total Public Social Expenditures (ADL models with 3-year LRMs)

\begin{tabular}{|c|c|c|c|c|c|c|c|c|}
\hline \multirow[b]{2}{*}{ Independent Variables } & \multicolumn{4}{|c|}{ All FA } & \multicolumn{4}{|c|}{ Large $F A$} \\
\hline & (1) & (2) & (3) & (4) & (5) & (6) & (7) & $(8)$ \\
\hline$\Delta$ Public Social Expenditure $\mathrm{t}-1$ & $\begin{array}{c}0.21 \text { *** } \\
(0.05)\end{array}$ & $\begin{array}{c}0.20 \text { *** } \\
(0.05)\end{array}$ & $\begin{array}{c}0.21 * * * \\
(0.05)\end{array}$ & $\begin{array}{c}0.20 * * * \\
(0.05)\end{array}$ & $\begin{array}{c}0.19 * * * \\
(0.05)\end{array}$ & $\begin{array}{c}0.18 * * * \\
(0.05)\end{array}$ & $\begin{array}{c}0.20 * * * \\
(0.05)\end{array}$ & $\begin{array}{c}0.18 * * * \\
(0.05)\end{array}$ \\
\hline FA [d] (LRM) & $\begin{array}{l}-0.05 \\
(0.10)\end{array}$ & $\begin{array}{c}0.11 \\
(0.10)\end{array}$ & $\begin{array}{c}0.09 \\
(0.11)\end{array}$ & & $\begin{array}{c}-0.49 * * \\
(0.21)\end{array}$ & $\begin{array}{c}-0.37^{*} \\
(0.21)\end{array}$ & $\begin{array}{c}0.09 \\
(0.26)\end{array}$ & \\
\hline FA [d] * Left Government [d] (LRM) & & $\begin{array}{c}-0.59 * * * \\
(0.19)\end{array}$ & & & & $\begin{array}{c}-1.17 * * * \\
(0.44)\end{array}$ & & \\
\hline FA [d] * Broad Coalition [d] (LRM) & & & $\begin{array}{l}-0.37 * \\
(0.21)\end{array}$ & & & & $\begin{array}{c}-1.00^{* *} \\
(0.45)\end{array}$ & \\
\hline FA, Left, Broad Gov. [d] (LRM) & & & & $\begin{array}{c}-0.49 * * \\
(0.25)\end{array}$ & & & & $\begin{array}{c}-1.62 * * * \\
(0.60)\end{array}$ \\
\hline FA, Left, Narrow Gov. [d] (LRM) & & $2.58 * *$ & & $\begin{array}{l}-0.19 \\
(0.18)\end{array}$ & & $2.75^{* * * *}$ & & $\begin{array}{l}-0.98 * \\
(0.55)\end{array}$ \\
\hline FA, Non-Left, Broad Gov. [d] (LRM) & & (t-value $)$ & & $\begin{array}{l}-0.20 \\
(0.22)\end{array}$ & & $(t$-value $)$ & & $\begin{array}{c}-0.77 * * \\
(0.34)\end{array}$ \\
\hline FA, Non-Left, Narrow Gov. [d] (LRM) & & & & $\begin{array}{l}0.20 * * \\
(0.10)\end{array}$ & & & & $\begin{array}{c}0.14 \\
(0.22)\end{array}$ \\
\hline Broad Coalition $[\mathrm{d}]_{\mathrm{t}}$ & $\begin{array}{l}-0.04 \\
(0.07)\end{array}$ & $\begin{array}{l}-0.05 \\
(0.07)\end{array}$ & & & $\begin{array}{l}-0.04 \\
(0.07)\end{array}$ & $\begin{array}{l}-0.04 \\
(0.07)\end{array}$ & & \\
\hline Left Government $[\mathrm{d}]_{\mathrm{t}}$ & $\begin{array}{r}0.03 \\
(0.07)\end{array}$ & & $\begin{array}{c}0.02 \\
(0.07)\end{array}$ & & $\begin{array}{c}0.01 \\
(0.07)\end{array}$ & & $\begin{array}{c}0.01 \\
(0.07)\end{array}$ & \\
\hline Public Social Expenditure $t-1$ & $\begin{array}{c}-0.11 * * * \\
(0.02)\end{array}$ & $\begin{array}{c}-0.11 * * * \\
(0.02)\end{array}$ & $\begin{array}{c}-0.11 * * * \\
(0.02)\end{array}$ & $\begin{array}{c}-0.11 * * * \\
(0.02)\end{array}$ & $\begin{array}{c}-0.10 * * * \\
(0.02)\end{array}$ & $\begin{array}{c}-0.10 * * * \\
(0.02)\end{array}$ & $\begin{array}{c}-0.11 * * * \\
(0.02)\end{array}$ & $\begin{array}{c}-0.10 * * * \\
(0.02)\end{array}$ \\
\hline GDP Growth $\mathrm{t}$ & $\begin{array}{c}-0.18 * * * \\
(0.02)\end{array}$ & $\begin{array}{c}-0.18 * * * \\
(0.02)\end{array}$ & $\begin{array}{c}-0.18 * * * \\
(0.02)\end{array}$ & $\begin{array}{c}-0.18 * * * \\
(0.02)\end{array}$ & $\begin{array}{c}-0.18 * * * \\
(0.02)\end{array}$ & $\begin{array}{c}-0.18 * * * \\
(0.02)\end{array}$ & $\begin{array}{c}-0.18 * * * \\
(0.02)\end{array}$ & $\begin{array}{c}-0.18 * * * \\
(0.02)\end{array}$ \\
\hline GDP Growth $\mathrm{t}-1$ & $\begin{array}{r}0.04 \\
(0.02)\end{array}$ & $\begin{array}{r}0.04 \\
(0.02)\end{array}$ & $\begin{array}{c}0.04 * \\
(0.02)\end{array}$ & $\begin{array}{r}0.04 * \\
(0.02)\end{array}$ & $\begin{array}{c}0.04 * \\
(0.02)\end{array}$ & $\begin{array}{r}0.04 * \\
(0.02)\end{array}$ & $\begin{array}{c}0.04 * \\
(0.02)\end{array}$ & $\begin{array}{l}0.05^{* *} \\
(0.02)\end{array}$ \\
\hline$\Delta$ Unemployment $\mathrm{t}$ & $\begin{array}{l}0.08 * * \\
(0.04)\end{array}$ & $\begin{array}{l}0.08 * * \\
(0.04)\end{array}$ & $\begin{array}{l}0.08 * * \\
(0.04)\end{array}$ & $\begin{array}{l}0.08 * * \\
(0.04)\end{array}$ & $\begin{array}{l}0.09 * * \\
(0.04)\end{array}$ & $\begin{array}{l}0.09 * * \\
(0.03)\end{array}$ & $\begin{array}{l}0.08 * * \\
(0.04)\end{array}$ & $\begin{array}{c}0.09 * * * \\
(0.03)\end{array}$ \\
\hline$\Delta$ Unemployment $\mathrm{t}-1$ & $\begin{array}{c}0.07^{*} \\
(0.04)\end{array}$ & $\begin{array}{c}0.07 * \\
(0.04)\end{array}$ & $\begin{array}{c}0.07 * \\
(0.04)\end{array}$ & $\begin{array}{l}0.08 * * \\
(0.04)\end{array}$ & $\begin{array}{l}0.08 * * \\
(0.04)\end{array}$ & $\begin{array}{l}0.09 * * \\
(0.04)\end{array}$ & $\begin{array}{l}0.08^{* *} \\
(0.04)\end{array}$ & $\begin{array}{c}0.10^{* * *} \\
(0.04)\end{array}$ \\
\hline$\Delta$ Openness $\mathrm{t}$ & $\begin{array}{c}-0.02 * * * \\
(0.01)\end{array}$ & $\begin{array}{c}-0.03 * * * \\
(0.01)\end{array}$ & $\begin{array}{c}-0.03 * * * \\
(0.01)\end{array}$ & $\begin{array}{c}-0.03 * * * \\
(0.01)\end{array}$ & $\begin{array}{c}-0.02 * * * \\
(0.01)\end{array}$ & $\begin{array}{c}-0.02 * * * \\
(0.01)\end{array}$ & $\begin{array}{c}-0.02 * * * \\
(0.01)\end{array}$ & $\begin{array}{c}-0.02 * * * \\
(0.01)\end{array}$ \\
\hline Elderly Population (\% of total) $\mathrm{t}-1$ & $\begin{array}{l}0.07 * * \\
(0.03)\end{array}$ & $\begin{array}{l}0.07 * * \\
(0.03)\end{array}$ & $\begin{array}{c}0.08 * * * \\
(0.03)\end{array}$ & $\begin{array}{c}0.08 * * * \\
(0.03)\end{array}$ & $\begin{array}{l}0.06 * * \\
(0.03)\end{array}$ & $\begin{array}{l}0.06 * * \\
(0.03)\end{array}$ & $\begin{array}{l}0.07 * * \\
(0.03)\end{array}$ & $\begin{array}{c}0.07 * * * \\
(0.02)\end{array}$ \\
\hline $\begin{array}{l}\Delta \quad \text { Social Security Contributions } \\
(\% \text { total tax revenue })_{t}\end{array}$ & $\begin{array}{l}0.09 * * * \\
(0.02)\end{array}$ & $\begin{array}{l}0.08 * * * \\
(0.02)\end{array}$ & $\begin{array}{l}0.08 * * * \\
(0.02)\end{array}$ & $\begin{array}{c}0.08 * * * \\
(0.02)\end{array}$ & $\begin{array}{l}0.08 * * * \\
(0.02)\end{array}$ & $\begin{array}{l}0.08 * * * \\
(0.02)\end{array}$ & $\begin{array}{l}0.08 * * * \\
(0.02)\end{array}$ & $\begin{array}{l}0.08 * * * \\
(0.02)\end{array}$ \\
\hline Party System Fractionalization t-1 & $\begin{array}{c}-0.01 * * \\
(0.01)\end{array}$ & $\begin{array}{c}-0.01 * \\
(0.01) \\
\end{array}$ & $\begin{array}{l}-0.01 \\
(0.01)\end{array}$ & $\begin{array}{l}-0.01 \\
(0.01) \\
\end{array}$ & $\begin{array}{l}-0.01 \\
(0.01) \\
\end{array}$ & $\begin{array}{c}-0.01 * \\
(0.01) \\
\end{array}$ & $\begin{array}{c}-0.01 * \\
(0.01) \\
\end{array}$ & $\begin{array}{c}-0.01 * \\
(0.01) \\
\end{array}$ \\
\hline $\mathrm{N}$ & 466 & 466 & 466 & 466 & 466 & 466 & 466 & 466 \\
\hline $\mathrm{R}^{2}$ & 0.68 & 0.69 & 0.69 & 0.69 & 0.69 & 0.69 & 0.70 & 0.70 \\
\hline
\end{tabular}

Entries are OLS coefficients with panel-corrected standard errors in parentheses. Coefficients for country and year fixed effects and constant are not reported. Estimates for components of LRMs (i.e. lags of 'Left Government' or 'Broad Coalition' as well as contemporaneous and lagged versions of interaction terms) are not reported.

$*<0.10 ; * *<0.05 ; * * *<0.01$ 


\section{References}

Alesina, A., \& Ardagna, S. (2009). Large Changes in Fiscal Policy: Taxes versus Spending. NBER Working Paper 15438.

Alexiadou, D. (2013). In Search of Successful Reform: The Politics of Opposition and Consensus in OECD Parliamentary Democracies. West European Politics, 36(4), 704-725.

Armingeon, K. (2012). The Politics of Fiscal Responses to the Crisis of 2008-2009. Governance: An International Journal of Policy, Administration, and Institutions, 25(4), 543-565

Armingeon, K., Knöpfel, L., Weisstanner, D., \& Engler, S. (2014). Comparative Political Data Set I 1960-2012. Bern: Institute of Political Science, University of Berne.

AUTHORS. (2014).

Birchfeld, V., \& Crepaz, M. M. L. (1998). The impact of constitutional structures and collective and competitive veto points on income inequality in industrialized democracies. European Journal of Political Research, 34(2), 175-200.

Bonoli, G. (2000). The Politics of Pension Reform. Institutions and Policy Change in Western Europe. Cambridge: Cambridge University Press.

Bonoli, G., \& Natali, D. (Eds.). (2013). The Politics of the New Welfare State. Oxford: Oxford University Press.

Cameron, D. R. (2012). European Fiscal Responses to the Great Recession. In N. Bermeo \& J. Pontusson (Eds.), Coping with Crisis: Government Reactions to the Great Recession (pp. 91-129). New York: Russel Sage

Crepaz, M. M. L. (1996). Consensus versus Majoritarian Democracy. Political Institutions and Their Impact on Macroeconomic Performance and Industrial Disputes in 18 Industrialized Democracies. Comparative Political Studies, 29(1), 4-26.

Crepaz, M. M. L. (1998). Inclusion versus Exclusion: Political Institutions and Welfare Expenditures. Comparative Politics, 31(1), 61-80.

De Boef, S., \& Keele, L. (2008). Taking Time Seriously. American Journal of Political Science, 52(1), 184-200.

Devries, P., Guajardo, J., Leigh, D., \& Pescatori, A. (2011). A New Action Based Dataset of Fiscal Consolidation. IMF Working Paper, WP/11/128.

Esping-Andersen, G. (1990). The Three Worlds of Welfare Capitalism. Princeton: Princeton University Press.

Green-Pedersen, C. (2002). The Politics of Justification. Party Competition and WelfareState Retrenchment in Denmark and the Netherlands from 1982 to 1998. Amsterdam: Amsterdam University Press.

Hall, P. (1986). Governing the Economy. The Politics of State Intervention in Britain and France. New York/Oxford: Oxford University Press.

Häusermann, S., Picot, G., \& Geering, D. (2013). Rethinking Party Politics and the Welfare State - Recent Advances in the Literature. British Journal of Political Science, 43(1), 221-240.

Heston, A., Summers, R., \& Aten, B. (2012). Penn World Table Version 7.1. Center for International Comparisons of Production, Income and Prices at the University of Pennsylvania, Nov 2012.

Hibbs, D. A., Jr. (1977). Political Parties and Macroeconomic Policy. The American Political Science Review, 71(4), 1467-1487. 
Hicks, A. M., \& Swank, D. H. (1992). Politics, Institutions, and Welfare Spending in Industrialized Democracies, 1960-82. American Political Science Review, 86(3), 658-674.

Huber, E., \& Stephens, J. D. (2001). Development and Crisis of the Welfare State: Parties and Policies in Global Markets. Chicago: University of Chicago Press.

Hübscher, E. (2015). The Politics of Fiscal Consolidation Revisited. Journal of Public Policy, electronic pre-publication.

Hübscher, E., \& Sattler, T. (2014). Fiscal Consolidation under Electoral Risk. SSRN Electronic Journal.

IMF. (2010). World Economic Outlook. Recovery, Risk and Rebalancing. October 2010. Washington, D.C.: International Monetary Fund.

IMF. (2012). Fiscal Monitor. Taking Stock: A Progress Report on Fiscal Adjustment. October 2012. Washington, D.C.: International Monetary Fund.

Jacobs, A. M. (2011). Governing for the Long Term. Democracy and the Politics of Investment. Cambridge: Cambridge University Press.

Jensen, C., \& Mortensen, P. B. (2014). Government Responses to Fiscal Austerity: The Effect of Institutional Fragmentation and Partisanship. Comparative Political Studies, 47(2), 143-170.

Kitschelt, H. (2001). Partisan Competition and Welfare State Retrenchment. When Do Politicians Choose Unpopular Policies? In P. Pierson (Ed.), The New Politics of the Welfare State (pp. 265-302). Oxford: Oxford University Press.

Kittel, B., \& Obinger, H. (2003). Political Parties, Institutions, and the Dynamics of Social Expenditure in Times of Austerity. Journal of European Public Policy, 10(1), 20-45.

Korpi, W. (1983). The Democratic Class Struggle. London: Routledge \& Kegan Paul.

Korpi, W., \& Palme, J. (2003). New Politics and Class Politics in the Context of Austerity and Globalization: Welfare State Regress in 18 countries, 1975-95. American Political Science Review, 97(3), 425-446.

Lijphart, A. (2008). Thinking about Democracy. Power sharing and majority rule in theory and practice. London/New York: Routledge.

Lijphart, A. (2012). Patterns of Democracy: Government Form and Performance in ThirtySix Countries. 2nd edition. New Haven: Yale University Press.

Mulas-Granados, C. (2006). Economics, Politics and Budgets. The Political Economy of Fiscal Consolidations in Europe. New York, NY: Palgrave Macmillan.

OECD. (2010a). Labour Force Statistics: Summary Tables. OECD Employment and Labour Market Statistics (database). from OECD

OECD. (2010b). Revenue Statistics: Comparative Tables. OECD Tax Statistics (database). from OECD

OECD. (2012). OECD Economic Outlook No. 91. OECD Economic Outlook: Statistics and Projections (database). from OECD

Pierson, P. (1994). Dismantling the Welfare State? Reagan, Thatcher and the Politics of Retrenchment. Cambridge: Cambridge University Press.

Pierson, P. (2001). Coping with Permanent Austerity: Welfare State Restructuring in Affluent Democracies. In P. Pierson (Ed.), The New Politics of the Welfare State (pp. 410-456). Oxford: Oxford University Press.

Ross, F. (2000). Beyond Left and Right: The New Partisan Politics of Welfare. Governance, 13(2), 155-183.

Schmidt, M. G. (2010). Parties. In F. Castles, S. Leibfried, J. Lewis, H. Obinger \& P. Chris (Eds.), The Oxford Handbook of the Welfare State (pp. 211-226). Oxford: Oxford University Press. 
Seki, K., \& Williams, L. K. (2014). Updating the Party Government data set. Electoral Studies, 34, 270-279.

Smith, D. A., \& Brame, R. (2003). Tobit Models in Social Science Research. Sociological Methods \& Research, 31(3), 364-388.

Tavares, J. (2004). Does right or left matter? Cabinets, credibility and fiscal adjustments. Journal of Public Economics, 88(12), 2447-2468.

Tsebelis, G. (2002). Veto Players: How Political Institutions Work. Princeton: Princeton University Press.

Volkens, A., Lehmann, P., Merz, N., Regel, S., Werner, A., \& Schultze, H. (2014). The Manifesto Data Collection. Manifesto Project (MRG/CNP/MARPOR). Version 2014b. Berlin: Wissenschaftszentrum Berlin für Sozialforschung (WZB).

Von Hagen, J., \& Strauch, R. (2001). Fiscal Consolidations: Quality, Economic Conditions, and Success. Public Choice, 109(3/4), 327-346.

Wagschal, U., \& Wenzelburger, G. (2008a). Haushaltskonsolidierung. Wiesbaden: Verlag für Sozialwissenschaften.

Wagschal, U., \& Wenzelburger, G. (2008b). Roads to Success: Budget Consolidations in OECD Countries. Journal of Public Policy, 28(03), 309-339.

Wagschal, U., \& Wenzelburger, G. (2012). When do Governments Consolidate? A Quantitative Comparative Analysis of 23 OECD Countries (1980-2005). Journal of Comparative Policy Analysis: Research and Practice, 14(1), 45-71.

Wenzelburger, G. (2009). The Analysis of Budget Consolidations: Concepts, Research Design and Measurement. Journal of Economic and Social Measurement, 31(4), 269-291.

Wenzelburger, G. (2014). Fact or Fiction? Welfare Cuts and Fiscal Adjustments. Journal of Public Policy, 43(1), 63-92.

Wilensky, H. (1975). The Welfare State and Equality. Structural and ideological roots of public expenditures. Berkeley, Los Angeles, London: University of California Press.

Woldendorp, J., Keman, H., \& Budge, I. (2000). Party Government in 48 Democracies. Composition-Duration-Personnel. Dordrecht etc.: Kluwer Academic Publishers.

Wooldridge, J. M. (2013). Introductory Econometrics. A Modern Approach (International Edition) (5th ed.). Andover: South-Western Cengage Learning. 


\section{Online Appendix -Choosing the path of austerity}

\section{Table A1: Variable Operationalization \& Sources}

\section{Total Public Social Expenditure}

Annual change rates (first differences), percentage of GDP. Level version (centered) included as control variable.

Source: OECD Social Expenditure Statistics (OECD 2012b)

\section{Fiscal Adjustment (FA) Episode}

All FA: Dummy = 1 whenever there was a FA program in a given country-year

Large FA: Dummy $=1$ when size of FA policy measures $>1.5 \%$ of GDP

Source: Devries et al. (2011)

\section{Left Government Partisanship}

Dummy $=1$ if $>50 \%$ of cabinet posts occupied by left parties.

Source: Armingeon et al. (2014)

\section{Broad Policy Coalition}

Dummy $=1$ when government is a surplus coalition, single or multi-party minority, or caretaker government; dummy $=0$ for single-party majority governments or minimal winning coalitions.

Source: Armingeon et al. (2014)

\section{Economic Growth}

Growth of real GDP

Source: OECD Economic Outlook.

\section{Unemployment Rate}

Unemployment rate as a percentage of civilian labor force.

Source: OECD Employment and Labour Market Statistics.

\section{Openness}

Measured as total trade (sum of imports and exports) as a percentage of GDP, at 2005 constant prices.

Source: Penn World Table.

\section{Elderly Population}

Population 65 and over as a percentage of total population (centered).

Source: OECD Employment and Labour Market Statistics.

\section{Social Contributions as Percentage of Taxes}

Social security contributions as a percentage of GDP divided by total tax revenues as a percentage of GDP. Source: OECD Tax Statistics.

Party System Fractionalization

Legislative (based on seat shares) fractionalization of the party system according to the Rae index (centered). Source: Armingeon et al. (2014). 
Table A2: Summary Statistics for all variables and observations used in the analysis

\begin{tabular}{|l|r|r|r|r|}
\hline Variable & \multicolumn{1}{|l|}{ Mean } & \multicolumn{1}{l|}{ Std. Dev. } & \multicolumn{1}{l|}{ Max } \\
\hline$\Delta$ Public Social Expenditure t & 0.25 & 0.93 & -2.40 & 5.10 \\
\hline$\Delta$ Public Social Expenditure t-1 & 0.19 & 0.82 & -2.40 & 5.10 \\
\hline FA [d] & 0.34 & 0.47 & 0 & 1 \\
\hline FA Large [d] & 0.08 & 0.27 & 0 & 1 \\
\hline Left Government [d] t & 0.29 & 0.45 & 0 & 1 \\
\hline Broad Coalition [d] t & 0.44 & 0.50 & 0 & 1 \\
\hline Public Social Expenditure t-1 * & 21.39 & 5.52 & 10.00 & 35.70 \\
\hline GDP Growth t & 2.43 & 2.43 & -8.54 & 11.27 \\
\hline GDP Growth t-1 & 2.63 & 2.06 & -6.00 & 11.27 \\
\hline$\Delta$ Unemployment t & 0.03 & 1.16 & -3.32 & 6.71 \\
\hline$\Delta$ Unemployment t-1 & 0.00 & 1.08 & -3.32 & 5.06 \\
\hline$\Delta$ Openness t & 0.58 & 4.62 & -26.17 & 17.60 \\
\hline Elderly Population $(\%$ of total) t-1 * & 14.42 & 2.41 & 9.34 & 22.10 \\
\hline$\Delta$ Social Security Contributions t & 0.05 & 1.02 & -4.61 & 4.29 \\
\hline Party System Fractionalization t-1 $*$ & 67.97 & 10.94 & 40.91 & 88.98 \\
\hline \multicolumn{2}{|r|}{ Notes: $n=466(16$ countries 1982-2009 plus Austria 1992-2009). } \\
\hline * Variables centered for the empirical analysis \\
\hline
\end{tabular}


Table A3: ADL models robustness checks

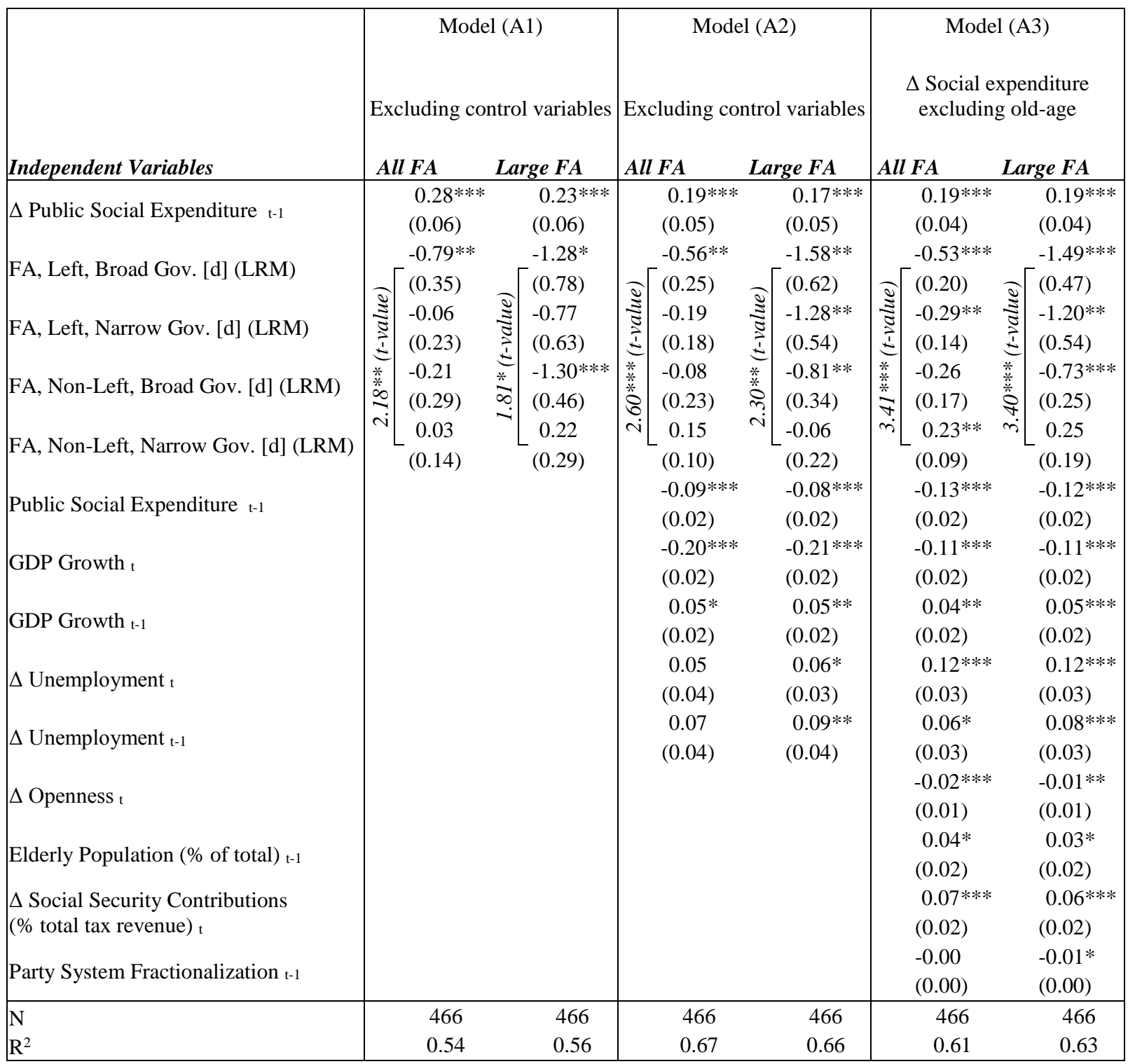


Table A3 (continued): ADL models robustness checks

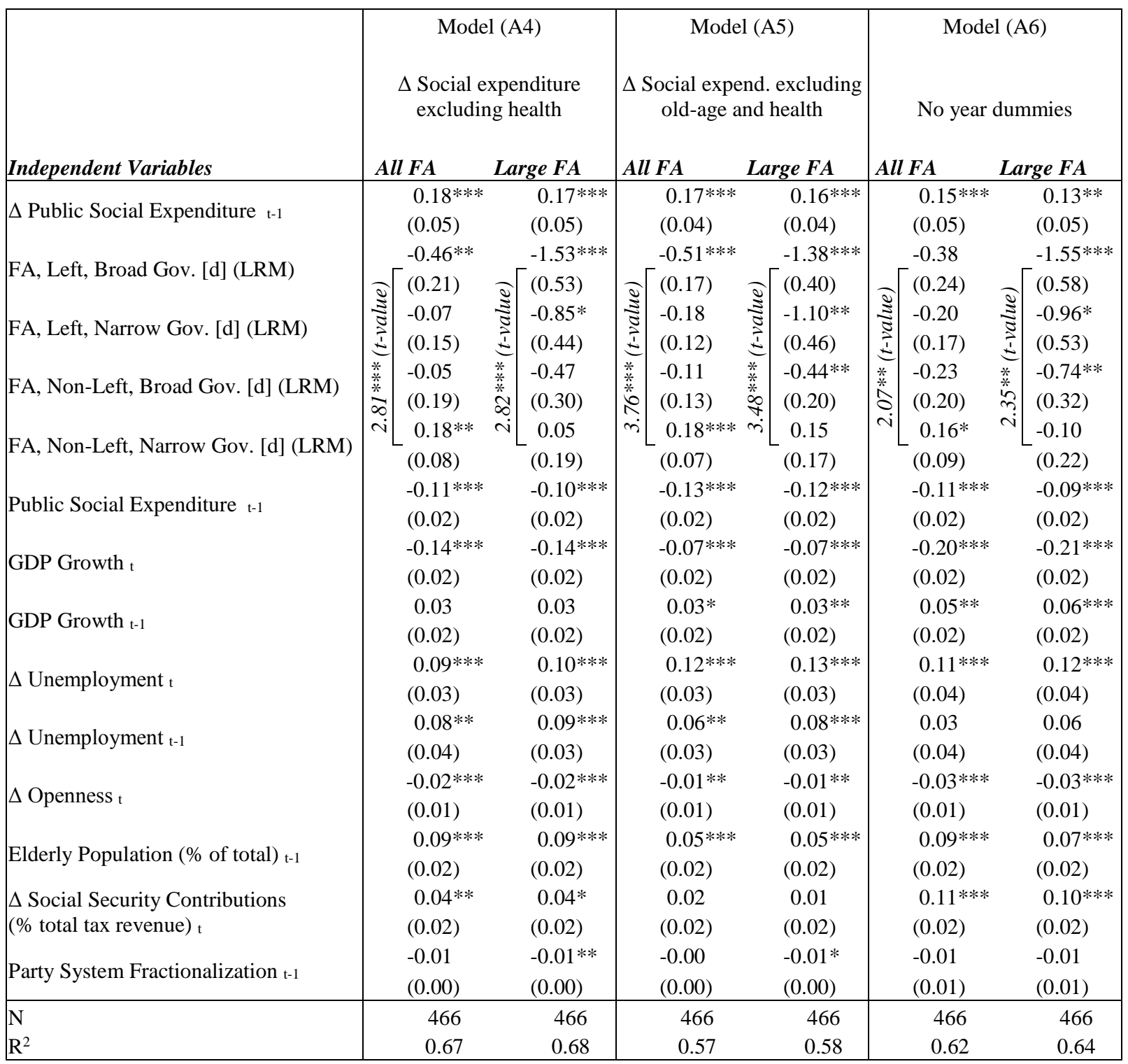


Table A3 (continued): ADL models robustness checks

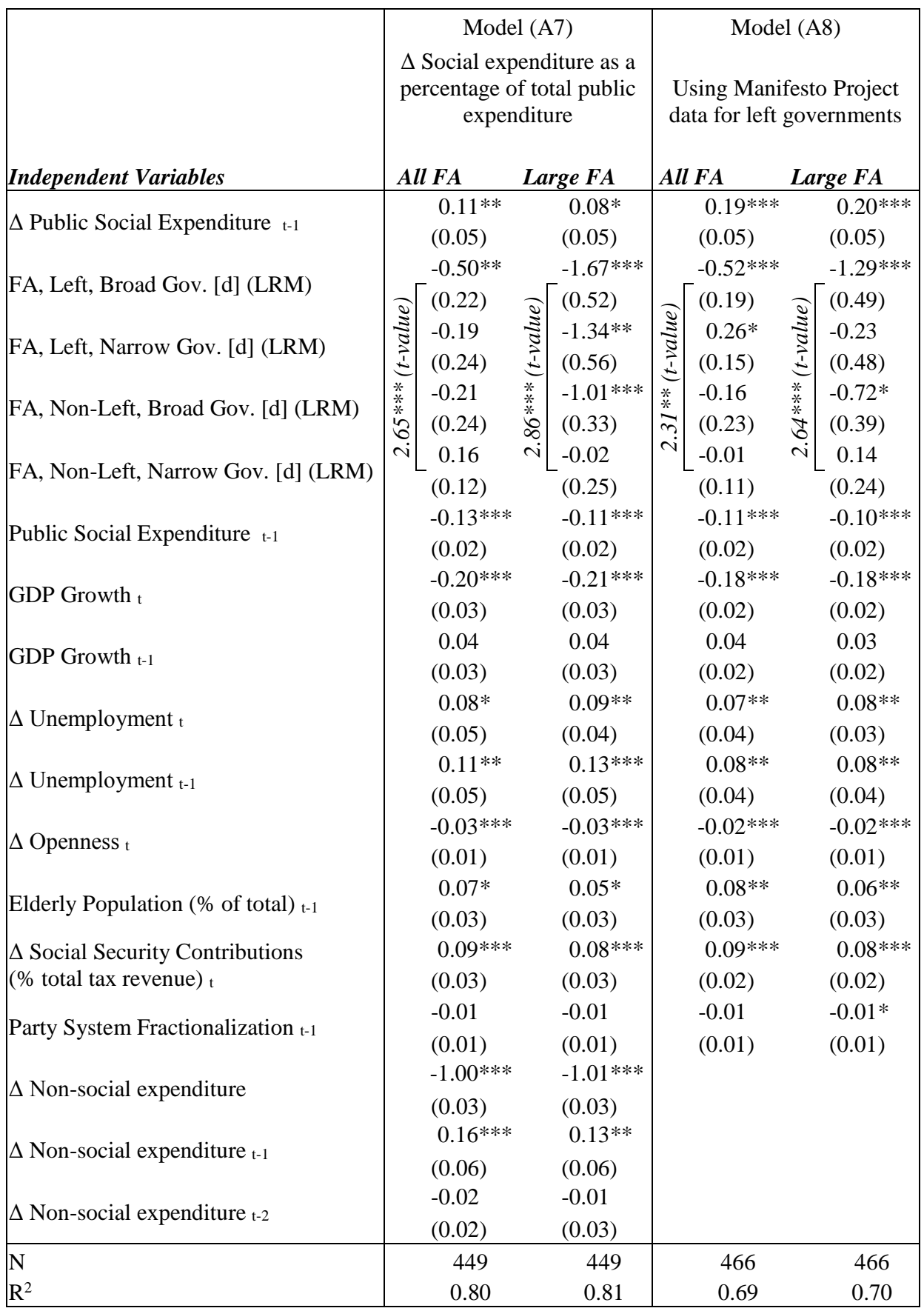

Note: All robustness tests based on Model 4 (All FA) and Model 8 (Large FA). Entries are OLS coefficients with panelcorrected standard errors in parentheses. Coefficients for country and year fixed effects and constant are not reported. Estimates for components of LRMs (i.e. lags of 'Left Government' or 'Broad Coalition' as well as contemporaneous and lagged versions of interaction terms) are not reported.

$$
*<0.10 ; * *<0.05 ; * * *<0.01
$$


Figure A1: Predicted changes in social expenditure for left/broad and non-left/narrow governments
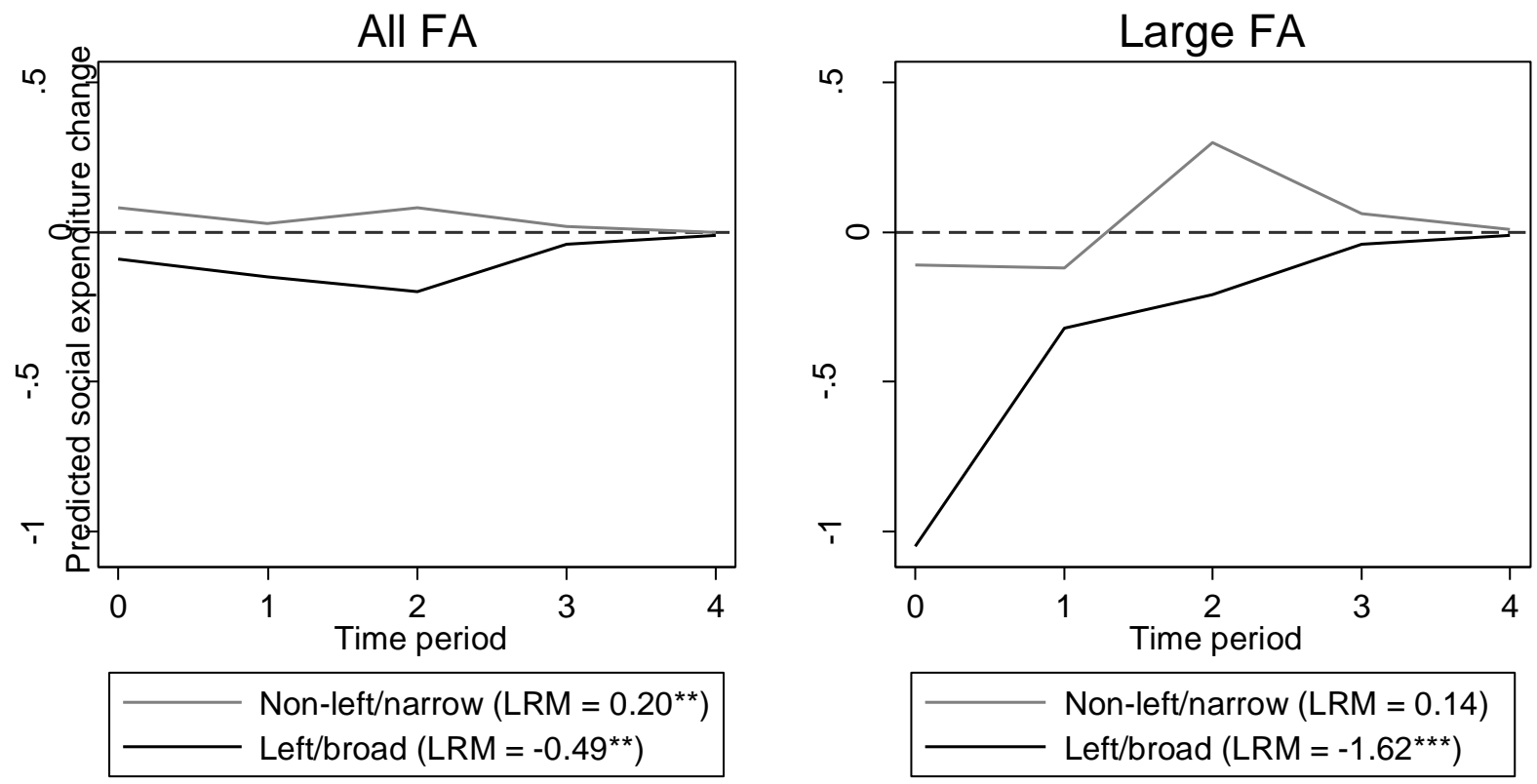

Note: Lines represent 'impulse response functions', i.e. the response of $Y_{t}$ to an impulse shock in $X_{t}(D e$ Boef and Keele 2008), calculated on the basis of Models 4 and 8. Social expenditure change measured in percentage of GDP. 


\section{Methodological concerns: Robustness tests and endogeneity}

We ran additional robustness tests for our analyses (regression estimates available upon request). First, our findings are robust to alternative operational definitions, such as continuous variables instead of dummies for the FA variables, the modification of the threshold constructing the dummy for left governments, using a continuous partisanship variable in separate models or using data from the Manifesto Project ${ }^{1}$, and an alternative coalition measure, where broad coalitions are minority or multi-party governments with a certain threshold of parliamentary support (see section 3). Second, our findings are robust against including a number of additional controls, such as institutional variables for federalism and bicameralism, and a dummy variable for Eurozone membership, as well as excluding controls (see models A1 and A2 in Table A3). Third, our main result suggested by models 4 and 8 - essentially an identification of those combinations of government type and partisan complexion that are most conducive or obstructive to welfare-state-driven fiscal adjustment - is robust to the exclusion of any of the 17 countries in the data set. ${ }^{2}$

A final issue concerns the possibility of endogeneity in our explanation. It could be the case, that both left-wing governments and broad policy coalitions exhibit a higher propensity for large fiscal adjustments to begin with, which is in turn correlated with a greater reliance on social spending cuts. Although recent research points to such complex influences of political factors on fiscal adjustment programs (AUTHORS, 2014; Hübscher, 2015; Hübscher $\&$ Sattler, 2014), we need to differentiate between the decision to consolidate on the one hand, and the size of that consolidation on the other. Using Tobit models, Hübscher (2015)

\footnotetext{
${ }^{1}$ Source: Volkens et al. (2014). We calculated governments' annual left-right scores from the Manifesto Project dataset following the procedure laid out by Seki and Williams (2014) based on their update of the Party Government data set by Woldendorp et al. (2000). We then created the group dummies from our Models 4 and 8 (left/broad etc.) using the sample median of the manifesto left-right score as a cutoff for our left dummy. In these models, the group differences between left/broad and non-left/narrow remain significant $(\mathrm{t}=-2.31$ for all FA, $\mathrm{t}=-$ 2.64 for FA large).

${ }^{2}$ Excluding Spain leads to a result where the coefficient in model 4 for FA under left broad governments misses significance $(\mathrm{p}=0.31)$. Consequently, the difference of this group to the effect by non-left narrow governments is significant at the $87 \%$-level only. Given that these are two-sided tests of significance, we do not consider this finding to be too critical, though. When looking at large FA cases only in model 8, both estimates remain statistically significant at the $90 \%$-level even when Spain is excluded.
} 
essentially assumes that there is a uniform process influencing both the likelihood of fiscal adjustments and its size in the same direction (see Smith \& Brame, 2003). In an earlier publication on precisely that question, however, we found that likelihood and size might be detrimental: right-wing narrow coalitions have a higher likelihood to consolidate, yet their adjustment programs are likely to be of smaller size (AUTHORS, 2014). Therefore, it is unclear whether this really indicates an endogeneity issue with regard to the reliance of adjustments on welfare state spending.

Having said this, our tests show that neither the likelihood nor the sizes of FA under left-wing broad coalition governments are significantly different from the likelihood or size of the other three groups. More specifically, we apply two-sided t-tests comparing the mean likelihood of FA, as well as the mean size of FA, under each of the four types of government against the average of the three remaining governments. The results are shown in Table A4. For the group of left, broad coalition governments, the mean differences to the other governments are not statistically different from zero $(\mathrm{p}>0.20)$. We also test likelihood and size against each other group on its own (thus always excluding two groups). Here the only significant difference concerning left broad governments is that their adjustments are smaller in size than those of non-left broad governments $(\mathrm{p}=0.02)$. However, considering only large FA, this size difference is insignificant $(\mathrm{p}=0.67)$. Since-in contrast to non-left narrow governments - non-left broad governments are not the main group of reference to which we test and compare the effects of FA on social expenditure, we conclude that there are no systematic differences in the likelihood and size of FA among our types of governments that are endogenous to our main causal mechanisms. Moreover, the restrictive nature of our robustness tests, such as excluding whole country series from the sample, gives no rise to serious endogeneity concerns. 
Table A4: Comparing likelihood and size of FA under left/broad governments to other groups (two-sided t-tests)

\begin{tabular}{|c|c|c|c|c|}
\hline \multirow[b]{2}{*}{ Comparison } & \multicolumn{2}{|c|}{ All FA } & \multicolumn{2}{|c|}{ Large FA } \\
\hline & Probability of FA & Size of FA if $F A=1$ & Probability of FA & Size of FA if $F A=1$ \\
\hline Left/broad & $0.29(\mathrm{~N}=68)$ & $0.76(\mathrm{~N}=20)$ & $0.04(\mathrm{~N}=68)$ & $2.37(\mathrm{~N}=3)$ \\
\hline $\begin{array}{l}\text { Left/narrow + } \\
\text { non-left/broad + } \\
\text { non-left/narrow }\end{array}$ & $0.35(\mathrm{~N}=398)$ & $1.05(\mathrm{~N}=139)$ & $0.09(\mathrm{~N}=398)$ & $2.37(\mathrm{~N}=34)$ \\
\hline Difference & $0.06(p=0.38)$ & $0.28(p=0.22)$ & $0.04(p=0.25)$ & $0.00(p=1.00)$ \\
\hline Left/broad & $0.29(\mathrm{~N}=68)$ & $0.76(\mathrm{~N}=20)$ & $0.04(\mathrm{~N}=68)$ & $2.37(\mathrm{~N}=3)$ \\
\hline Left/narrow & $0.40(\mathrm{~N}=65)$ & $0.89(\mathrm{~N}=26)$ & $0.05(\mathrm{~N}=65)$ & $1.78(\mathrm{~N}=3)$ \\
\hline Difference & $0.11(p=0.20)$ & $0.13(p=0.55)$ & $0.00(p=0.96)$ & $-0.59(p=0.37)$ \\
\hline Left/broad & $0.29(\mathrm{~N}=68)$ & $0.76(\mathrm{~N}=20)$ & $0.04(\mathrm{~N}=68)$ & $2.37(\mathrm{~N}=3)$ \\
\hline Non-left/broad & $0.27(\mathrm{~N}=135)$ & $1.52(\mathrm{~N}=36)$ & $0.11(\mathrm{~N}=135)$ & $2.67(\mathrm{~N}=15)$ \\
\hline Difference & $-0.03(p=0.68)$ & $0.75 * *(p=0.02)$ & $0.07(p=0.11)$ & $0.30(p=0.67)$ \\
\hline Left/broad & $0.29(\mathrm{~N}=68)$ & $0.76(\mathrm{~N}=20)$ & $0.04(\mathrm{~N}=68)$ & $2.37(\mathrm{~N}=3)$ \\
\hline Non-left/narrow & $0.39(\mathrm{~N}=198)$ & $0.88(\mathrm{~N}=77)$ & $0.08(\mathrm{~N}=198)$ & $2.20(\mathrm{~N}=16)$ \\
\hline Difference & $0.09(p=0.16)$ & $0.11(p=0.60)$ & $0.04(p=0.31)$ & $-0.16(p=0.73)$ \\
\hline
\end{tabular}

Note: $* \mathrm{p}<0.10 ; * * \mathrm{p}<0.05 ; * * * \mathrm{p}<0.01$

AUTHORS. (2014).

Hübscher, E. (2015). The Politics of Fiscal Consolidation Revisited. Journal of Public Policy, electronic pre-publication.

Hübscher, E., \& Sattler, T. (2014). Fiscal Consolidation under Electoral Risk. SSRN Electronic Journal.

Seki, K., \& Williams, L. K. (2014). Updating the Party Government data set. Electoral Studies, 34, 270-279.

Smith, D. A., \& Brame, R. (2003). Tobit Models in Social Science Research. Sociological Methods \& Research, 31(3), 364-388.

Volkens, A., Lehmann, P., Merz, N., Regel, S., Werner, A., \& Schultze, H. (2014). The Manifesto Data Collection. Manifesto Project (MRG/CNP/MARPOR). Version 2014b. Berlin: Wissenschaftszentrum Berlin für Sozialforschung (WZB).

Woldendorp, J., Keman, H., \& Budge, I. (2000). Party Government in 48 Democracies. Composition-Duration-Personnel. Dordrecht etc.: Kluwer Academic Publishers. 